\title{
KUALITAS SENSORIS TELUR DARI BURUNG PUYUH YANG DIBERI AIR MINUM MENGANDUNG EKSTRAK BUAH PARE
}

\section{SENSORY QUALITY OF EGGS OF QUAILS GIVEN BITTER MELON FRUIT EXTRACT THROUGH DRINKING WATER}

\author{
S Julaeha' ${ }^{1 a}$, Anggraeni, dan R Handarini \\ 1Program Studi Peternakan Fakultas Pertanian Universitas Djuanda Bogor, Jl. Tol Ciawi No. 1, Kotak \\ Pos 35 Ciawi, Bogor 16720. \\ aKorespondensi: Siti juleha, E-mail: siti.julaeha@unida.ac.id
}

(Received: 06-10-2020; Accepted: 12-10-2020)

\begin{abstract}
Bitter melon (Momordica charantia) is a vine plant having oblong-shaped fruits with distinct warty exterior and bitter taste. The fruits contain B-carotene pigment which gives effect on yolk color. This study was aimed at assessing (hedonic and hedonic quality tests) the sensory quality of eggs of quails given bitter melon fruit extract through drinking water. The study was conducted at the Trial Farm of Department of Animal Science, Djuanda University, Bogor, in February to March 2019. Onehundred female quails aged 30 days and ready for their production phase were used. The birds were fed with commercial feed containing $20-22 \%$ crude protein (CP). A completely randomized design with 5 treatments and 4 replicates was used. Treatments consisted of $0 \%$ bitter melon fruit extract (R0, control), $2.5 \%$ bitter melon fruit extract $+97.5 \%$ water (R1), $5.0 \%$ bitter melon fruit extract + 95\% water (R2), 7.5\% bitter melon fruit extract $+92.5 \%$ water (R3), and $10.0 \%$ bitter melon fruit extract $+90 \%$ water (R4). Data were subjected to a Kruskal Wallis test. Measurements were taken on albumin color, yolk color, aroma, taste, and texture of eggs. Results of hedonic test showed that bitter melon fruit extract gave significant effects $(\mathrm{P}<0.05)$ on albumin color, yolk color, but not $(\mathrm{P}>0.05)$ on aroma, taste, and texture. Results of quality hedonic test gave significant effects $(\mathrm{P}<0.05)$ on albumin color, yolk color, aroma, taste, and texture. Eggs with the best sensory quality were produced by quails given drinking water containing $7.5 \%$ bitter melon fruit extract.
\end{abstract}

Key words: quail egg sensory quality, quail, bitter melon fruit extract

\begin{abstract}
ABSTRAK
Tanaman pare (Momordica Charantia) adalah jenis tumbuhan jalar yang mempunyai rasa pahit dan buahnya panjang bergerigi. Kandungan pare memiliki pigmen yang memengaruhi warna kuning telur yaitu B-karoten. Penelitian ini bertujuan untuk menguji kualitas sensoris telur puyuh (uji hedonik dan mutu hedonik) dari telur burung puyuh yang diberi ekstrak buah pare (EBP) pada air minum. Penelitian ini dilaksanakan selama 2 bulan dari bulan Februari - bulan Maret 2019. Penelitian ini dilaksanakan di Laboratorium Universitas Djuanda Bogor. Ternak yang digunakan 100 ekor puyuh betina yang berumur 30 hari siap produksi. Pakan yang diberikan adalah pakan komersil dengan PK $20-22 \%$. Rancangan penelitian yang digunakan yaitu Rancangan Acak Lengkap (RAL) 5 perlakuan dan 4 ulangan. Perlakuan terdiri atas R0 $=0 \% \mathrm{EBP}, \mathrm{R} 1=2,5 \% \mathrm{EBP}+97,5 \%$ air, R2 $=5 \% \mathrm{EBP}+95 \%$ air, R3 $=7,5 \%$ EBP $+92,5 \%$ air, R4 $: 10 \%$ EBP $+90 \%$ air. Data dianalisis menggunakan uji Kruskal Wallis. Peubah yang diamati yaitu uji hedonik dan uji mutu hedonik (warna putih telur,kuning telur, aroma, rasa dan tekstur). Hasil penelitian menyatakan bahwa pemberian ekstrak buah pare berpengaruh nyata $(P<0,05)$ terhadap warna putih telur, warna kuning telur dan tidak berpengaruh nyata $(P>0,05)$ terhadap aroma, rasa dan tekstur pada uji hedonik. Pada mutu hedonik nyata $(\mathrm{P}<0,05)$ terhadap warna putih telur, kuning telur, aroma, rasa dan tekstur. Kualitas sensoris terbaik dari telur puyuh yakni yang diberi air minum mengandung $7,5 \%$ ekstrak buah pare.
\end{abstract}

Kata kunci :kualitas sensoris telur puyuh, burung puyuh, ekstrak buah pare. 
S Julaeha, Anggraeni, R Handarini. 2020. Kualitas Sensoris Telur Dari Burung Puyuh Yang Diberi Air Minum Mengandung Ekstrak Buah Pare. Jurnal Peternakan Nusantara 6(2): 83-88.

\section{PENDAHULUAN}

Telur dan daging merupakan produk hasil ternak yang sangat digemari di Indonesia. Salah satu hewan ternak yang memiliki hasil produksi tersebuat adalah burung puyuh, burung puyuh dapat membantu kebutuhan protein hewani masyarakat. Harga yang relative murah dan mudah didapat, daging dan telur burung puyuh mengandung nutrisi yang baik. Ternak puyuh ini merupakan ternak yang dapat berproduksi dalam waktu cepat yaitu hanya dalam 40hari sudah bisa bertelur, usaha burung puyuh juga dapat dilakukan dengan modal yang relatif kecil dan lahan yang tidak terlalu luas (Departemen Pertanian 2012).

Puyuh merupakan unggas petelur yang sangat berpotensi untuk dikembangkan, khususnya telur dan dagingnya. Puyuh memiliki tingkat produksi telur yang baik, terdapat diurutan kedua setelah ayam ras petelur. Selain itu, daging puyuh pun tidak kalah dari daging ayam, daging puyuh mempunyai nilai gizi yang cukup tinggi, rasa yang lezat, gurih dan memiliki tekstur yang lembut (Wuryadi 2011).

Puyuh (Coturnix coturniz japonica) yaitu unggas darat yang produksi telurnya tinggi berkisar 250 - 300 butir/ekor/tahun, dan tubuhnya berukuran kecil. Menurut data (Direktorat Jenderal Peternakan dan Kesehatan Hewan 2017) Populasi puyuh di Indonesia pada tahun 2016 sebanyak 14.108 ekor dan tahun 2017 sebanyak 14.427 ekor. Produksi telur puyuh tahun 2016 mencapai 25,3 ton. Konsumsi telur puyuh per kapita/minggu dari satu tahun terakhir sebanyak 7.769 butir.

Berdasarkan analisis fitokimia, ekstrak pare dapat berperan sebagai antioksidan dengan ditemukannya kandungan flavonoid, tanin, saponin, steroid, dan terpenoid (Agus 2008), dari hasil penelitian (Wu dan LeanTeik 2008), diketahui ekstrak pare dalam air maupun etanol menunjukkan adanya kinerja antioksidan dalam penangkapan radikal DPPH yang lebih besar daripada vitamin E, yang disumbangkan oleh senyawa fenolik dan flavonoid nya.

Menurut (Tuan 2011) Kandungan $\beta$-karoten dalam pare lima X lebih besar dari wortel, (Naid et al. 2012) menambahkan, pada penelitian pare di Ternate disebutkan bahwa kandungannya sebesar 0,7822 mg/100 g. Vitamin lain yang terkandung dalam buah pare adalah vitamin $\mathrm{C}$
(BPOM 2004), yang berperan dalam kekuatan pembuluh darah, sebagai antimikrobia, dan sebagai metabolisme pembuangan kolester. Buah pare juga memiliki kandungan seperti alcaloid, momordicin, karotern, glikosida, saponin, vitamin A vitamin B, polipeptida dll (Apriyadi et al. 2012). Penelitian bertujuan untuk menguji kualitas sensoris telur burung puyuh yang diberi air minum mengandung ekstrak pare

\section{MATERI DAN METODE}

\section{Materi}

Penelitian ini dilaksanakan di Laboratorium Ternak Unggas Program Studi Peternakan Fakultas Pertanian Universitas Djuanda Bogor. Ternak yang digunakan yaitu burung puyuh betina 100 ekor umur 30 hari siap produksi, Ekstrak buah pare dan pakan komersil dengan kandungan PK 20-22\%.

Kandang yang digunakan pada penelitian ini menggunakan sistem sangkar yang dibuat dari kayu, kawat dan triplek sebagai penutup. Ukuran sangkar puyuh yang digunakan berukuran 87 x 56 × $35 \mathrm{~cm}$. Sangkar yang di gunakan yakni sangkar susun 4 tingkat. Peralatan yang digunakan yaitu tempat pakan, tempat minum, lampu, tabung gas, kompor, panci, baskom, parutan, saringan nasi, ember besar dan kecil, pisau, gelas ukur ukuran 100,500 dan $1000 \mathrm{ml}$, botol aqua, timbangan digital dan timbangan kiloan plastik, pisau cutter, nampan, alat tulis dan dokumentasi, piring sterofoam, kertas label dan form uji penilaian.

\section{Perlakuan}

Penelitian ini mengunakan metode rancangan acak lengkap dengan lima perlakuan dan empat ulangan. Perlakuan yang akan diberikan yaitu pemberian air minum mengandung:

P0 : ekstrak buah pare $0 \%$.

P1 : ekstrak buah pare 2,5\%.

P2 : ekstrak buah pare $5 \%$.

P3 : ekstrak buah pare 7,5\%.

P4 : ekstrak buah pare $10 \%$. 


\section{Rancangan Percobaan}

Data ditabulasi dan dianalisis dengan metode kruskal wallis, bila menunjukkan beda nyata $(\mathrm{P}<0.05)$ atau sangat nyata $(\mathrm{P}<0.01)$ dilanjutkan dengan uji beda rataan Duncan.

\section{Peubah yang Diamati}

Peubah yang diamati pada penelitian ini ialah uji sensoris yang terbagi menjadi dua yakni, uji hedonik dan uji mutu hedonik. Parameter yang diuji meliputi warna, aroma, rasa dan tekstur. Pada pengajian sampel diberi kode tiga angka disetiap perlakuan. Sebanyak 40 orang panels diminta memberikan penilaian tingkat kesukaannya dengan kisaran 1-5 (1 = sangat tidak suka, 2 = tidak suka, $3=$ netral, $4=$ suka, 5 = sangat suka) untuk Uji hedonik. Pengujian mutu hedonik dengan 4 kategori peubah dan skor penilaian dituangkan pada Tabel 1 .

Tabel 1 Skor Penilaian Uji Mutu Hedonik

\begin{tabular}{|c|c|c|c|}
\hline Peubah & & Skor & Kriteria \\
\hline & & & Sangat \\
\hline \multirow{8}{*}{\multicolumn{2}{|c|}{ Aroma }} & 1 & Beraroma Amis \\
\hline & & & Beraroma \\
\hline & & 2 & Amis \\
\hline & & 3 & Beraroma Amis \\
\hline & & & Beraroma \\
\hline & & 4 & Amis \\
\hline & & & Beraroma \\
\hline & & 5 & Amis \\
\hline \multirow{5}{*}{\multicolumn{2}{|c|}{ Tekstur }} & 1 & Sangat Tidak Kenyal \\
\hline & & 2 & Tidak Kenyal \\
\hline & & 3 & Kenyal \\
\hline & & 4 & Lebih Kenyal \\
\hline & & 5 & Sangat Kenyal \\
\hline \multirow{5}{*}{\multicolumn{2}{|c|}{$\begin{array}{l}\text { Warna Kuning } \\
\text { Telur }\end{array}$}} & 1 & Kuning Pucat \\
\hline & & 2 & Kuning \\
\hline & & 3 & Kuning Keorange \\
\hline & & 4 & Orange \\
\hline & & 5 & Orange Sekali \\
\hline \multirow{5}{*}{\multicolumn{2}{|c|}{$\begin{array}{l}\text { Warna } \\
\text { Telur }\end{array}$}} & 1 & Sangat TidakPutih \\
\hline & & 2 & Tidak Putih \\
\hline & & 3 & Putih \\
\hline & & 4 & Lebih Putih \\
\hline & & 5 & Sangat Putih \\
\hline \multirow{5}{*}{\multicolumn{2}{|c|}{ Rasa }} & 1 & Sangat Tidak Enak \\
\hline & & 2 & Tidak Enak \\
\hline & & 3 & Enak \\
\hline & & 4 & Lebih Enak \\
\hline & & 5 & Sangat Enak \\
\hline
\end{tabular}

\section{Prosedur Pelaksanaan}

Sebelum peneleitian dimulai dinding dan lantai kandang dibersihkan dan didesinfektan menggunakan antisep, setelah kandang bersih dan ruangan juga steril baru burung puyuh dimasukkan ke dalam kandang.

Ternak yang digunakan dilakukan proses adaptasi selama kurang lebih satu minggu dengan diberikan air minum yang telah dicampur ekstrak pare. Berikut prosedur pembuatan ekstrak buah pare.

Pilih buah yang masih segar berwarna hijau yang tidak terlalu tua

Buah pare di belah dua, lalu dipisahkan dari bijinya, kemudian di cuci

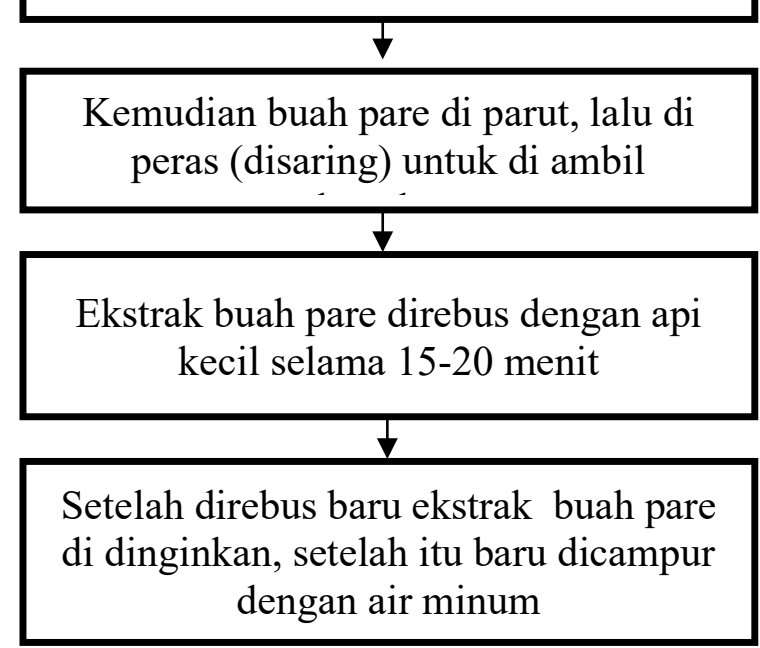

Gambar 1 Pembuatan ekstrak buah Pare Pakan yang digunakan adalah pakan komersil, jumlah yang diberikan 30gr/ ekor/ hari. Pemberian dilakukan pada pukul 08.00 WIB. Pemberian air minum dengan perlakuan EBP diberikan secara adlibitum namun terukur, pemberian air minum yang diberi Ekstrak buah pare (EBP) disajikan pada Tabel 2.

Tabel 2 Pemberian air minum

\begin{tabular}{ccccc}
\hline $\begin{array}{c}\text { Mulai } \\
\text { Perlakua } \\
\text { n (hari) }\end{array}$ & $\begin{array}{c}\text { Perlakua } \\
\mathrm{n}\end{array}$ & $\begin{array}{c}\text { Ekstra } \\
\mathrm{k} \\
\text { Buah } \\
\text { Pare } \\
(\mathrm{ml})\end{array}$ & $\begin{array}{c}\text { Air } \\
\text { minu } \\
\mathrm{m}\end{array}$ & $\begin{array}{c}\text { Jumlah } \\
\text { Pemberia } \\
\mathrm{n}\end{array}$ \\
\hline \multirow{5}{*}{$1-35$} & P0 & 0 & 2000 & 2000 \\
& P1 & 50 & 1950 & 2000 \\
& P2 & 100 & 1900 & 2000 \\
& P3 & 150 & 1850 & 2000 \\
& P4 & 200 & 1800 & 2000 \\
\hline
\end{tabular}




\section{HASIL DAN PEMBAHASAN}

\section{Uji Hedonik}

Tabel 3 Rataan nilai uji hedonik telur puyuh

\begin{tabular}{lcccccc}
\hline \multirow{2}{*}{ Peubah } & \multicolumn{5}{c}{ Perlakuan } & \multirow{2}{*}{ Rataan \pm Sd } \\
\cline { 2 - 6 } & R0 & R1 & R2 & R3 & R4 \\
\hline Warna PT & $3,37 \pm 0,89^{\mathrm{a}}$ & $3,3 \pm 0,79^{\mathrm{a}}$ & $3,67 \pm 0,76^{\mathrm{a}}$ & $4,12 \pm 0,93^{\mathrm{b}}$ & $3,62 \pm 0,95^{\mathrm{a}}$ & $3,61 \pm 0,08$ \\
Warna KT & $3,3 \pm 0,88^{\mathrm{a}}$ & $3,5 \pm 0,81^{\mathrm{a}}$ & $3,62 \pm 0,89^{\mathrm{a}}$ & $3,92 \pm 1,04^{\mathrm{b}}$ & $3,67 \pm 0,88^{\mathrm{a}}$ & $3,60 \pm 0,08$ \\
Aroma & $3,37 \pm 0,80$ & $3,37 \pm 0,77$ & $3,4 \pm 1,05$ & $3,65 \pm 0,89$ & $3,5 \pm 1,03$ & $3,45 \pm 0,12$ \\
Rasa & $3,5 \pm 0,78$ & $3,7 \pm 0,68$ & $3,47 \pm 0,87$ & $3,72 \pm 0.96$ & $3,7 \pm 0,91$ & $3,61 \pm 0,11$ \\
Tekstur & $3,7 \pm 0,79$ & $3,7 \pm 0,79$ & $3,62 \pm 0,92$ & $3,65 \pm 0,89$ & $3,77 \pm 0,86$ & $3,68 \pm 0,05$ \\
\hline
\end{tabular}

Keterangan : PT $=$ Putih telur, KT $=$ Kuning telur. Huruf superskrip yang berbeda pada baris yang sama menunjukan perbedaan yang nyata $(\mathrm{P}<0,05$. R0 : 0\% Ekstrak buah pare, R1 : 2,5\% Ekstrak buah pare + 97,5\% Air, R2 : 5\% Ekstra buah pare $+95 \%$ air, R3 : 7,5\% Ekstrak buah pare + 92,5\% air, R4 : 10\% Ekstrak buah pare $+90 \%$ air).

Penilaian pada uji sensoris meliputi uji hedonik dan uji mutu hedonik. Uji hedonik dilakukkan untuk menilai tingkat kesukan panelis terhadap sampel dengan kisaran 1 - 5 (1=sangat tidak suka, $2=$ tidak suka, $3=$ netral, 4=suka, 5=sangat suka). Pengolahan data menggunakan uji kruskal wallis untuk mengetahui tingkat penerimaan dan penolakan panelis terhadap sampel.

Berdasarkan analisis kruskal wallis dari setiap perlakuan menunjukkan bahwa pemberian EBP pada air minum berpengaruh nyata $(\mathrm{P}<0.05)$ terhadap warna putih dan kuning telur tetapi tidak nyata $(\mathrm{P}>0,05)$ terhadap aroma, rasa dan tekstur.

Penilaian panelis terhadap uji hedonik warna putih telur dengan nilai paling tinggi ada pada $\mathrm{R}$ 3 dengan rataan nilai 4,12 menunjukkan panelis suka warna putih telur pada perlakuan ini, dibanding dengan $\mathrm{R} 0, \mathrm{R} 1, \mathrm{R} 2$ dan $\mathrm{R} 4$ yang menunjukkan kesukaan panelis nertal dengan nilai rataan kisaran 3 .

Penilaian panelis terhadap uji hedonik warna kuning telur dengan nilai tertinggi ada pada R3 dengan rataan nilai 3,92 yang berarti tingkat kesukaan panelis akan warna kuning telur pada kisaran netral-suka, lebih besar dibandingkan R0 dengan nilai rataan 3,3 dan R1 dengan rataan nilai 3,5 menunjukkan tinglat kesukaan berada pada kisarran netral saja.

Berdasarkan hasil analisis kruskal wallis nilai aroma tidak nyata $(\mathrm{P}>0,05)$ dengan rataan penilaian sebesar 3,45 yang menunjukkan tingkat kesukaan panellis akan aroma telur puyuh di kisaran 3 yaitu netral.

Berdasarkan hasil analisis kruskal wallis nilai rasa menunjukkan tidak nyata $(\mathrm{P}>0,05)$ dengan rataan nilai seluruh perlakuan 3,61 yang berarti tingkat kesukan pannelis pada kisaran enak. Dilihat pada tabel uji hedonik R1, R3 dan R4 dengan rataan 3,70 yang menunjukkan posisi lebih tingi dari perlakuan lainnya, tetapi masih pada daerah kisaran suka.

Berdasarkan hasil analysis kruskal wallis nilai tekstur menunjukkan tidak nyata $(\mathrm{P}>0,05)$ dengan rataan nilai seluruh perlakuan 3,68 yang menunjukkan bahwa panelis menilai netralsuka. Menurut Kastaman et al. (2010), factor yang mepengaruhi tekstur telur yaitu kadar air, dimana berkurangnya kadar air menimbulkan tekstur telur semakin keras

\section{Uji Mutu Hedonik}

Uji mutu hedonik meliputi warna putih telur, warna kuning telur, rasa, tekstur, dan aroma dengan penilaian 1-5 yang lebih spesifk (Tabel 5). Penilaian mutu hedonik diberikan panelis sesuai dengan alat indera yaitu mata (penglihatan), hidung (penciuman) dan lidah (pengecap rasa). Hasil rataan uji mutu hedonik pada setiap perlakuan disajikan dalam Tabel 4.

Berdasarkan analisis kruskal wallis nilai warna putih telur berbeda nyata $(P<0,05)$. Penilaian panellis terhadap warna putih telur pada uji mutu hedonik nilai tertinggi ada pada R3 yakni pemberian EBP 7,5\% + air 92,5\% dengan nilai rataan 4 yaitu menunjukkan warna putih telur lebih putih. Pada R4 dan R2 menunjukkan hasil yang sama yaitu putih dengan rataan 3,25 sedangkan R0 dan R1 menunjukkan hasil tidak putih dengan rataan 2,72 . 
Tabel 4 Rataan Uji Mutu Hedonik Telur Puyuh

\begin{tabular}{|c|c|c|c|c|c|c|}
\hline \multirow[b]{2}{*}{ Peubah } & \multicolumn{5}{|l|}{ Perlakuan } & \multirow[b]{2}{*}{ Rataan $\pm \mathrm{Sc}$} \\
\hline & R0 & R1 & R2 & R3 & R4 & \\
\hline Warna PT & $2,75 \pm 0,74^{\mathrm{a}}$ & $2,7 \pm 0,56^{\mathrm{a}}$ & $3,25 \pm 0,70^{b}$ & $4 \pm 0,87^{c}$ & $3,25 \pm 0,77^{b}$ & $3,19 \pm 0,11$ \\
\hline Warna KT & $1,72 \pm 0,84^{\mathrm{a}}$ & $1,95 \pm 0,74^{\mathrm{a}}$ & $2,3 \pm 0,82^{b}$ & $2,32 \pm 0,99^{b}$ & $2,1 \pm 0,84^{b}$ & $2,07 \pm 0,09$ \\
\hline Aroma & $2,65 \pm 0,94^{\mathrm{a}}$ & $3 \pm 0,90^{\mathrm{b}}$ & $3,17 \pm 1,00^{\mathrm{b}}$ & $3,4 \pm 0,95^{b}$ & $3,02 \pm 0,94^{b}$ & $3,04 \pm 0,03$ \\
\hline Rasa & $3 \pm 0,50$ & $3,27 \pm 0,67$ & $3,32 \pm 0,82$ & $3,32 \pm 0,99$ & $3,47 \pm 0,90$ & $3,27 \pm 0,19$ \\
\hline Tekstur & $2,95 \pm 0,59^{\mathrm{a}}$ & $3,07 \pm 0,69^{b}$ & $3,17 \pm 0,71^{b}$ & $3,35 \pm 0,94^{b}$ & $3,22 \pm 0,86^{\mathrm{b}}$ & $3,15 \pm 0,14$ \\
\hline
\end{tabular}

Keterangan : $\mathrm{PT}=$ Putih telur, KT $=$ Kuning telur, Huruf superskrip yang berbeda pada baris yang sama menunjukan perbedaan yang nyata $(\mathrm{P}<0,05$. R0 : 100\% air, R1 : 2,5\% Ekstrak buah pare + 97,5\% Air, R2 : 5\% Ekstra buah pare + 95\% air, R3 : 7,5\% Ekstrak buah pare + 92,5\% air, R4 : 10\% Ekstrak buah pare + 90\% air).

Berdasarkan hasil analysis kruskal wallis perlakuan memberikan hasil yang berbeda nyata $(\mathrm{P}<0,05)$ terhadap nilai kuning telur. Perlakuan pada R2, R3, dan R4 memiliki warna kuning telur yang sedikit lebih tinggi dengan rataan 2,24 di banding dngan R0 dan R1 dengan rataan 1,83. Menurut Yuwanta (2010), warna kuning telur ditentukan oleh kandungan karotenoid (xantofil) yang berasal dari komponen pakan, seperti biji jagung ataupun hijauan.

Berdasarkan analisis kruskal wallis nilai aroma pada telur puyuh berbeda nyata $(\mathrm{P}<$ $0,05)$. Pada R0 yaitu pemberian air $100 \%$ tanpa penambahan EBP memiliki nilai lebih rendah dibanding dengan perlakuan lainnya yang diberikan campuran ekstrak buah pare. Nilai tertinggi ada pada ada pada R4 dengan nilai rataan 3,35 ini menunjukan aroma telur butung puyuh beraroma amis.

Berdasarkan analisis kruskal wallis nilai rasa berbeda nyata $(\mathrm{P}>0,05)$. Pada perlakuan R0 dengan rataan 3,00 memiliki posisi lebih kecil dibanding perlakuan lainnya, nilai mutu hedonik yang paling tinggi terdapat pada R4 dengan rataan 3,47 menunjukkan rasa telur puyuh ada dalam kissaran enak, sedangkan R2 dan R3 memiliki nilai yang sama yakni 3,32 tetapi pada $\mathrm{R} 1$ dengan nilai rataan 3,27 lebih kecil dari $\mathrm{R} 2$ dan $\mathrm{R} 3$ dengan nilai rataan 3,32.

Berdasarkan analisis kruskal wallis nilai tekstur menunjukkan berbeda nyata $(\mathrm{P}<0,05)$. Pada perlakuan R0 dengan rataan 2,95 memiliki posisi yang rendah dari perlakuan lainnya. Sedangkan nilai rataan paling tinggi terdapat pada R3 dengan rataan 3,35 yaitu menunjukkan tekstur telur puyuh ada dalam kisaran kenyal.

\section{KESIMPULAN DAN IMPLIKASI}

\section{Kesimpulan}

Hasil penelitian menunjukkan bahwa pemberian ekstrak buah pare pada air minum berbeda nyata $(\mathrm{P}<0,05)$ terhadap warna putih telur dan kuning telur, tetapi tidak berbeda nyata $(\mathrm{P}>0,05)$ terhadap aroma, rasa dan tekstur pada uji hedonik. Pada mutu hedonik berbeda nyata $(\mathrm{P}<0,05)$ terhadap warna putih telur, warna kuning telur, aroma, dan tekstur, tetapi tidak berbeda nyata $(\mathrm{P} 0>0,05)$ terhadap rasa. Kualitas sensoris terbaik dari telur burung puyuh yang diberi air minum mengandung 7,5\% ekstrak buah pare.

\section{Implikasi}

Disarankan untuk meningkatkan nilai kesukaan pada warna putih telur, warna kuning telur, aroma dan tekstur telur puyuh sebaiknya menambahkan 7,5\% ekstrak buah pare.

\section{DAFTAR PUSTAKA}

Agus L. 2008. Potensi Antioksidan Pare (Momordica charantia L.) Sebagai Antidiabetika Pada Tikus Jantan (Sprague Dewley) Diabetik

Apriyadi F, Hadisoewignyo L, Hermanu L. 2012. Optimization tablet of leaves extract of bitter melon. Jurnal Sain Med 4 (2): 68-73.

[Badan POM]. 2004. Mengenal beberapa tanaman yang digunakan masyarakat sebagai antidiabetik untuk membantu menurunkan kadar gula dalam darah. Info POM 5 (3): 6

[Departemen Pertanian]. 2012. Pedoman Penataan Budidaya Puyuh. 
https://www.academia.edu/8760060/Pedoman p enataan puyuh 2012. [12 Februari 2019].

[Direktorat Jendral Peternakan dan Kesehatan Hewan]. 2015. Populasi dan produksi peternakan di Indonesia.

Naid T, Muflihunna A, Madi MIO. 2012. Analisis Kadar $\beta$ karoten pada buah pare (Momordica charantia L.) secara spektrofotometri UV VIS. Majalah Farmasi dan Farmakologi 16 (3): 129.

Tuan PA. 2011. Carotenoid content and expression of phytoene synthase and phytoene desaturase genesnin bitter melon (Momordica charantia). Food Chem 126: 322330.
Yuwanta T. 2010. Telur dan Kualitas Telur. Gadjah Mada University Press, Yogyakarta

Wu SJ, Lean-Teik Ng. 2008. Antioxidant and free radical scavenging activities of wild bitter melon (Momordica charantia Linn. Var. abbreviata Ser) in Taiwan. LWT 41: 323-330.

Wuryadi S. 2011. Beternak dan Bisnis Puyuh. Cetakan Pertama . Jakarta (ID) : PT. Agromedia Pustaka 